\title{
Effects of Ișlamic Banking on Financial Market Outcomes in GCC Countries and Iran
}

\author{
Robert Morrissey \\ Bachelor of Arts, Economics, Arabic \\ Cornell University, 2012
}

Islamic banking and finance have become increasingly widespread over the past two decades, particularly in Muslim-majority countries in the Middle East, North Africa, and Southeast Asia. This paper uses country-level data to examine how growing Islamic banking sectors have affected financial market outcomes in six countries. The analysis is split into two parts, first testing the hypothesis that countries with large Islamic banking sectors were less affected by the 2008 financial crisis than countries with strictly conventional banking systems, and second testing the hypothesis that emerging Islamic banking sectors have had a positive effect on private saving in countries with large Muslim populations. I find evidence that the banking systems of countries with large Islamic banking sectors fared no better at providing credit during the financial crisis than conventional alternatives, but do find evidence supporting a positive correlation between Islamic bank development and private saving.

\section{Introduction}

"O you who believe, you shall not take riba, compounded over and over. Observe God, that you may succeed." (Al-'Imran 3:130)

Developed to comply with Islamic or Shari'ah law, Islamic financial institutions and structures have spread rapidly over the past decade and today represent a significant share of the financial system in many countries. Islamic banking assets worldwide are estimated to exceed $\$ 1$ trillion, with surveys indicating that one in two Muslims, representing some 700 million people, would opt for an Islamic alternative if it were available (Oliver Wyman, 2009). Some regions have witnessed particularly rapid growth; Islamic banking assets in the Gulf Cooperation Council ${ }^{2}$ (GCC) have been estimated to grow from less than $10 \%$ of total banking assets in 2003 to representing approximately $22 \%$ of total assets in 2008 , or some $\$ 285$ billion. This corresponds to an average annual growth rate of $35 \%$ or nearly twice that of conventional bank assets over the same period (Coughlin, 2010).

Islamic banks are money-making financial intermediaries much like conventional banks, but in order to meet the requirements of Shari'ah they must adhere to four major principles. A prohibition on charging riba (interest) is the primary difference between Islamic banks and conventional banks, derived from the notion that charging interest is a form of exploitation and inherently inconsistent with Islamic values of fairness; the literal translation of riba is "excess". Islamic banks are also prohibited from speculation, in the form of risky or uncertain business ventures, and from financing haram (illegal) activities such as businesses involved in the production of alcoholic beverages or pork. Finally, Islamic banks are compelled to donate part of their profits to benefit society in the form of zakat, one of the five pillars of Islam (Imam \& Kpodar, 2010).

Despite its remarkable growth, or perhaps because of it, Islamic finance has not been without controversy. Proponents of Islamic finance argue that it is more equitable than traditional financial models and that Islamic banks are more resistant to crises due to the avoidance of speculation and to risk-sharing inherent in the Islamic banking model. Critics, however, argue that Islamic banks are different than conventional banks in name only, with someclaiming that, because of underdeveloped 
standards and a lacking regulatory-supervisory framework, Islamic banks are in fact more risky than conventional banks (Musa, 2010).

To date, empirical work on Islamic banks and the economies of countries where they have developed is thin and the impact of this development remains poorly understood. As Islamic banks are expected to sustain asset growth in the near future (Oliver Wyman, 2009), it is now critical for governments to understand the effects of Islamic banking on financial market outcomes in their countries. Is the growth of Islamic banking, on the balance, a positive or negative economic development? This paper presents a comparative study, in two areas, of the countries in which Islamic banks have come to represent the largest shares of the overall banking systems. I examine the

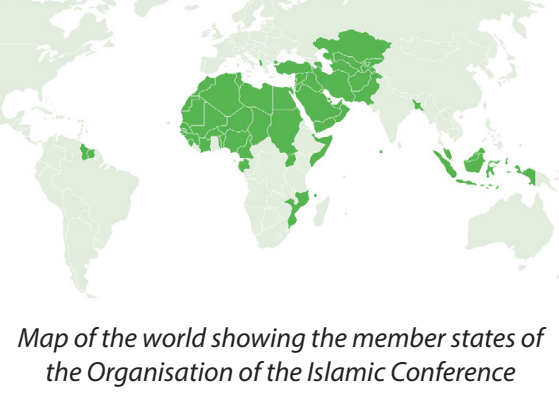

resilience of these countries' banking systems in providing credit during the years of the 2008 financial crisis, as well as how private savings rates have behaved in the presence of increased Islamic banking.

On the first account, comparing the growth rate of bank-generated credit in countries with high shares of Islamic banking during the crisis to various benchmarks, I find that, contrary to the view held by proponents of Islamic banking, Islamic banking countries fared no better than conventional banking countries during the recent financial crisis. On the second account, using a regression framework, I find that the development of Islamic banks in countries with large Muslim populations is positively correlated with private saving. While this paper does not claim to make a fundamental judgment of good or bad, it does find evidence that Islamic banking growth seems to have improved financial inclusion in Muslim countries.

\section{Background}

\section{What is "Islamic finance"?}

"Islamic finance" describes the body of Islamic jurisprudence related to economics and financial matters. Indeed, this is a vast field, with Islamic takaful insurance, governmentissued sukuk bonds, and Islamic banks all falling under today's "Islamic finance" umbrella. For the descriptive section of this paper I focus primarily on Islamic commercial banks, as they are most relevant to the financial market outcomes we are concerned with. Islamic banks are broadly defined as financial intermediaries that allow Muslims to deposit money and finance projects in accordance with religious requirements (World Bank \& International Monetary Fund, 2005).

\section{The spread of Islamic banking}

The origins of today's Islamic commercial banks can be traced to experiments with Islamic modes of financing in rural Egypt some four decades ago (Imam \& Kpodar, 2010). The Islamic Development Bank, one of the earliest successful Islamic banks and today one of the largest in the world, was established in Jeddah in 1975 and Malaysia also emerged as an earlyadopter and innovator in the industry. Around this time, several countries including Pakistan (1979), Iran (1983), and Sudan (1984) attempted to restructure their entire economies to comply with Islamic principles (Iqbal \& Molyneux, 2005). These experiments were met with varying degrees of success; today only Iran claims to maintain a fully Shariah-compliant economy and banking system. As GCC countries emerged as financial hubs and oil revenues exploded at the beginning of the $21^{\text {st }}$ century, Islamic banking sectors in the region began growing rapidly and were recognized by a number of central banks as distinct components of the banking system. Today, as we will see in data 
below, Iran, Saudi Arabia, Bahrain, Kuwait, Qatar, and the United Arab Emirates boast the most significant Islamic banking sectors in the world.

Financing structures and sources of funds for Islamic commercial banks

While in theory the Qu'ran provides a framework for permissible economic activity, in practice there is no absolute scale of which banking activities qualify as shariah-compliant and which do not. The transactions of Islamic commercial banks are typically certified by "shariah-compliance boards" of religious scholars, employed by the banks themselves, or in the case of Iran by guidelines that have been established by the country's Central Bank. Despite these efforts, Islamic banks have been criticized as being only cosmetically different than conventional banks and not truly in the spirit of Islamic law (Khan, 2010). This debate is relevant for our discussion insofar as understanding whether or not Islamic banks have legitimately altered the economics of banking systems they have penetrated or simply the perceptions of some devout Muslims vis-à-vis the use of formal banking institutions will be important in interpreting our results. Let us briefly consider the major financing structures and sources of funding employed by Islamic commercial banks.

\section{Mudaraba}

The mudaraba financing model is a profit and loss sharing (PLS) structure in which profits are shared between the stakeholders of a project. One group of stakeholders provides capital, in this case a bank, while another group, an entrepreneur or business, provides management of the project and profits are shared according to a predetermined formula. In the event of a loss, the financiers assume the financial loss and the managers stand to lose their time and effort.

\section{Musharaka}

Musharaka financing is a PLS financing model similar to the mudaraba model, except that all partners partake in management of the project. A legal contract drawn up beforehand determines the ultimate division of profits and losses.

\section{Murabaha}

In the murabaha model, a non-PLS form of financing, an asset is purchased at a given price and then resold at a predetermined markup. For example, instead of a conventional home mortgage, an Islamic bank using the murabaha structure would purchase a home on behalf of a customer and allow the customer to live in the home while retaining full ownership of the asset. Customers typically make periodic payments to the bank until they have repurchased the entire asset, at which point ownership is transferred from the bank to the customer.

ljara

The ijara model is a non-PLS model similar to murabaha financing, except that instead of a bank reselling an asset to its customer, it leases it to the customer over the period of the contract in exchange for periodic payments. Unlike a murabaha contract where payments are typically of a fixed amount, payments in the ijara case are tied to a market rate (e.g. LIBOR) and may vary. Additionally, when an ijara contract expires, ownership of the asset returns to the bank instead of transferring to the customer.

The four financing structures described above fall into two distinct categories: profit and loss sharing (PLS) financing, or non-profit and loss sharing (non-PLS) financing. This first type of financing, represented by the mudaraba and musharaka structures, requires either a partnership or direct equity-sharing in a project by all parties. PLS financing is considered preferable by Islamic legal scholars and is fundamentally different from conventional debt-based financing models. Non-PLS contracts must be based on real underlying assets, but do not require profits and losses to 
be shared amongst stakeholders. In practice, the cash flows in a murabaha or ijara structure are virtually indistinguishable from those of a traditional loan (Khan, 2010). The distinction between PLS and non-PLS structures also exists on the liabilities side of Islamic bank balance sheets.

\section{Sources of funding}

The most important liabilities on a conventional commercial bank's balance sheet are typically customer deposits, longterm debt, and loans from other financial institutions. Because the Islamic interbank market is relatively undeveloped and Islamic

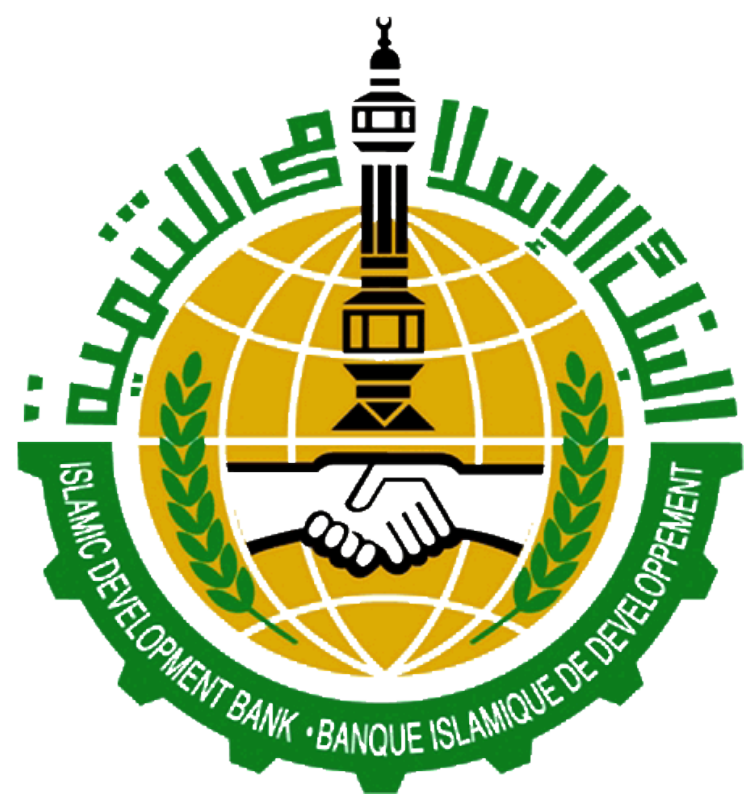

Islamic Development Bank Logo

banks are prohibited from issuing traditional interest-bearing debt securities such as bonds and commercial paper, today's Islamic banks structure their balance sheets somewhat differently. Two important sources of funding for Islamic banks are non-interest-bearing deposit accounts, similar to demand deposits with conventional banks, and profit and loss (PLS) sharing investment accounts, resembling conventional bank savings accounts but without guaranteed returns (Hasan \& Dridi, 2010). The latter source can also be thought of as a reverse-mudaraba structure, with depositors providing capital and a bank providing management. On their own, these PLS and non-interest bearing funding sources would eliminate much of the liquidity risk faced by conventional banks due to mismatches in returns on assets and liabilities (Musa, 2010). In practice, however, Islamic banks have also begun to rely on non-PLS reversemurabaha transactions and to issue Shariahcompliant sukuk bonds. These structures, like non-PLS financing, offer guaranteed returns to depositors and mimic the cash flows of conventional deposits or debt securities.

Interestingly, while PLS structures are preferable from an Islamic legal standpoint and likely reduce liquidity risk, non-PLS structures currently dominate Islamic banks worldwide. According to Warde (2000), PLS financing only accounts for about $5 \%$ of transactions by Islamic financial institutions worldwide and a similar breakdown is given for GCC countries by Ali (2011). Even in Saudi Arabia, a country distinguished by its strict Islamic practices, the Islamic Development Bank saw 92\% of its income in 2007 come from non-PLS structures such as murabaha and ijara (Khan, 2010). This imbalance indicates that while Islamic banks satisfy many devout Muslims in name, the underlying financial structures they employand thus the risks inherent in Islamic bankingin many ways resemble those of conventional banks. This is an important distinction that I will return to throughout the paper.

Did Islamic banks prove better than conventional banks at providing credit during the crisis?

Proponents of Islamic banking have argued that Islamic banks may be more stable than conventional banks in times of crises because (1) PLS funding sources allow losses on the asset side of Islamic bank balance sheets to be passed along to depositors and (2) Islamic banks are prohibited from investing in financial products not backed by real assets, such as mortgage-backed securities. If these claims are true, the presence of Islamic banks could 
prove a boon in times of financial uncertainty. Empirical evidence has been mixed.

Musa (2010) measures the comparative strength of Islamic and conventional banks in the United Arab Emirates using bank-level data from the period immediately following the 2008 subprime crisis. His results show that while Islamic banks exhibited lower Z-Scores ${ }^{3}$ both before and during the financial crisis, indicating a higher risk of becoming illiquid, they were significantly less impacted by the crisis when it hit. In their 2010 paper using data from 77 Islamic banks in 21 countries, Martin Cihák and Heiko Hesse compare the Z-Scores of Islamic and conventional banks over the period 1993 to 2004, finding that while small Islamic banks tend to be financially stronger than small conventional banks, the opposite is true when comparing their larger counterparts.

Finally, in a recently published IMF working paper entitled"The Effects of the Global Crisis on Islamic and Conventional Banks: A Comparative Study", Maher Hasan and Jemma Dridi look at bank-level data from a sample of Islamic and conventional banks in Bahrain, Jordan, Kuwait, Malaysia, Qatar, Saudi Arabia, Turkey, and the United Arab Emirates. Results show that Islamic banks grew more rapidly in terms of credit and assets, but that the two groups performed similarly in terms of profitability and external bank ratings.

Most previous research about Islamic bank performance during crises has used banklevel data and achieved inconclusive results. In order to capture the actual performance of banking systems in countries with a significant presence of Islamic banking, as well as possible interactions between the Islamic and conventional banking sectors in these countries, I will compare the growth rates of domestic credit provided by the banking systems in countries with Islamic banking to growth rates in countries without Islamic banking, both before and during the crisis.

Have Islamic banks increased private saving?
Whether or not the economics of Islamic banks are materially different than those of commercial banks, the perception of Islamic banks as Islamic may, on its own, have had positive consequences in countries where Islamic banking has developed. Observers have pointed to the existence of a large, underbanked population of devout Muslims in many countries as one explanation for the rapid growth of Islamic banking over the past decade (Imam \& Kpodar, 2010). Data on financial inclusion in the region is limitedthe Middle East and North Africa was the most poorly covered region in the 2010 Financial Access report published by the Consultative Group to Assist the Poor (CGAP) and The World Bank Group-but if individuals indeed lived for years without satisfactory financial institutions with which to deposit their money, the development of Islamic commercial banks has likely increased financial inclusion in many countries, rather than simply displacing conventional commercial banks. In order to understand this relationship between Islamic bank development and financial inclusion, I will also look at how private savings rates have behaved in countries with the highest levels of Islamic bank penetration, controlling for the factors Masson, Bayoumi, and Samiei identify in their 1998 paper on the determinants of private saving.

\section{Data And Methodology}

One challenge to empirical work on the macroeconomic impacts of Islamic banking is the lack of comprehensive data about Islamic banks and the size of Islamic banking sectors in different countries. This paucity stems from the lack of an absolute framework to designate a bank as "Islamic" or "conventional" - a proposal even further complicated by the growing importance of conventional banks operating Islamic windows-compounded by relatively weak reporting to begin with in the countries with significant shares of Islamic banking. Previous researchers have relied on banks' selfdesignation as "Islamic" to construct datasets 
from bank-level data, but the size of the overall Islamic banking sector as well as the relative shares of Islamic and conventional banks in specific countries' banking systems is still a matter of some debate. Most estimates are similar to those used by Hasan \& Dridi in their working paper on Islamic and conventional banks during the 2008 crisis (Figure 1) and it is generally accepted that Iran and the five GCC countries excluding Oman are the current leaders in Islamic banking growth. I will refer to these six countries as the Islamic Banking Countries (IBCs) in my analysis.

Figure 1. Estimated Islamic Banking Market Share in Selected Countries

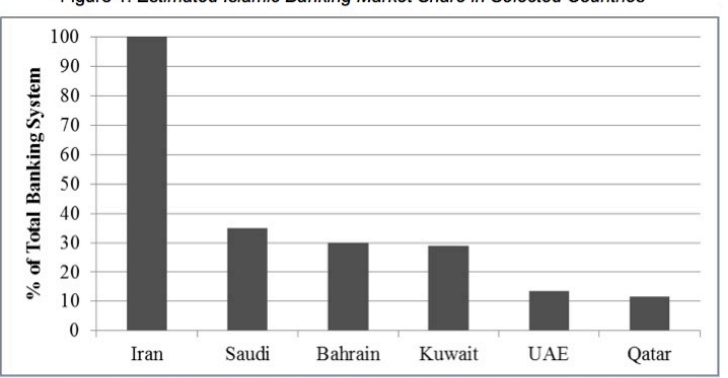

Source: The Effects of the Global Crisis on Islamic and Conventional Banks: A Comparative Study, Hasan \& Dridi (2008)

Table 1. The origins of Islamic banking in six countries.

\begin{tabular}{lll}
\hline Country & Year & Event \\
\hline Bahrain & 2000 & $\begin{array}{l}\text { Bahrain Monetary Agency establishes Prudential } \\
\text { Information and Regulations for Islamic Banks law }\end{array}$ \\
Iran & 1983 & $\begin{array}{l}\text { Law for Usury-free Banking Operations established after } \\
\text { nationalization of banking system in 1979 }\end{array}$ \\
Quatar & 2004 & $\begin{array}{l}\text { Amendment to Central Bank Law 32 brings Kuwait } \\
\text { Finance House under authority of Kuwait Central Bank }\end{array}$ \\
Saudi Arabia & 2005 & $\begin{array}{l}\text { Regulators allow conventional banks to establish Islamic } \\
\text { windows }\end{array}$ \\
U.A.E. & 2001 & $\begin{array}{l}\text { Conventional banks begin making their retail business } \\
\text { lines Sharia-compliant } \\
\text { Abu Dhabi Water and Electricity Authority issues sukuk } \\
\text { bonds to finance Shuweihat S1 IWPP project }\end{array}$ \\
\hline
\end{tabular}

Sources: Wilson (2009), Iqbal \& Molyneux (2004), Coughlin (2010), Collins \& Hills (2010).

\section{Provision of Credit}

For this section I use country-level data from the World Bank's World Development Indicators on the growth rate of domestic credit provided by banking systems. The behavior of credit growth differs greatly across countries at different income levels, but, as we see in Figure 2 , growth rates slowed across all income levels as credit markets dried up following the 2008 subprime mortgage crisis.
If the Islamic banking model is indeed more resistant to crises than conventional models, we may expect IBCs to have fared better at sustaining credit growth in 2009. In my analysis I compare average IBC performance to all three income aggregates, as well as each country to its relevant benchmark.

\section{Private Saving}

In their 1998 paper "International Evidence on the Determinants of Private Saving", Masson et al. use country-level data from 1971-1993 for a sample of industrial and developing countries to identify major determinants of private savings. In order to analyze the relationship between Islamic banking and private saving, I obtained similar variables to those identified by Masson et al. for the six IBCs over the period 1995-2010 from the International Monetary

Figure 2. Growth Rate of Domestic Credit Provided by Banking System: Three Income Aggregates

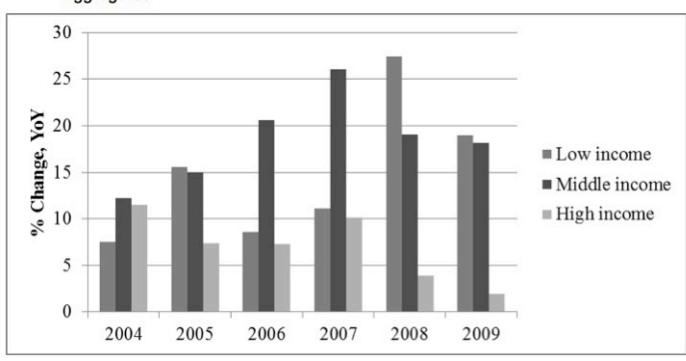

Source: World Development Indicators, World Bank Data Bank

Fund's World Economic Outlook (WEO), the World Bank's World Development Indicators (WDI), and the Economist Intelligence Unit (EIU). Private savings were calculated for each country as national savings minus the government budget surplus (EIU), and other variables included the government budget surplus (EIU), government current expenditure (WEO), the growth rate of real GDP (WEO), consumer price inflation (EIU), the real shortterm interest rate (EIU), per capita income relative to the US (WEO), the current account balance (EIU), and the age dependency ratio of non-working age individuals to working age individuals (WDI).

The lack of reliable data for Islamic banking growth over time made it difficult to identify a 
meaningful panel variable for Islamic banking market share, but by identifying the point in time at which Islamic banking was liberalized or formally recognized by governments or central banks, I was able to construct a binary or "dummy" variable for each country tracking the beginning of significant Islamic banking growth. These events are summarized in Table 1 above.

\section{Results}

\section{Provision of Credit}

Comparing the average performance of the six Islamic Banking Countries to the three income aggregates from above, we see initially that, as a group, the IBCs outgrew other countries in the years leading up to the crisis, but performed significantly worse in 2008 and 2009.

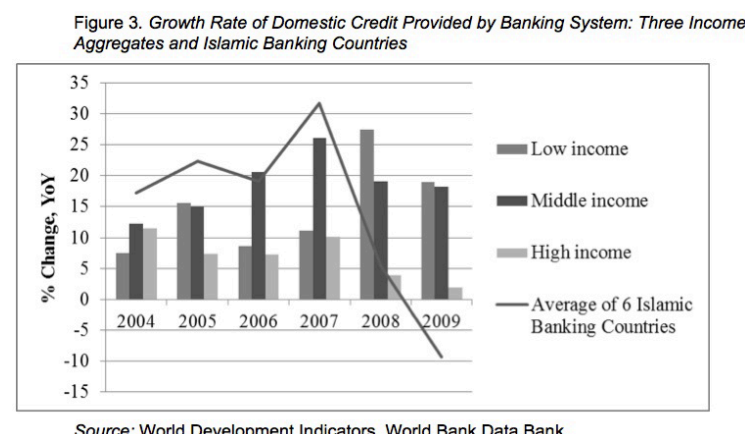

Table 2 presents results on a country-bycountry basis, looking at the average growth rate of credit leading up to the crisis from 20002007 , the average growth rate during the crisis in 2008-2009, and relative change between these two periods. Countries are compared to their corresponding income aggregates, with an average calculated for the high-income IBCs. The performance of IBCs appears somewhat better individually -in particular, the banking sectors of Bahrain, Qatar, and the United Arab Emirates grew their credit provision faster during the crisis period than over the early period-but still fails to illustrate the supposed resilience of Islamic banks in the face of crisis.

On the whole, it does not appear that the presence of Islamic banks allowed Iran or GCC countries to maintain credit growth any better than other countries during the global financial crisis. This result may be because Islamic banks do not yet represent a large enough share of banking systems to have a noticeable impactalthough evidence from Iran's fully Shariahcompliant banking system would suggest otherwise-or, as discussed above, it may be because the economics of Islamic commercial banks are not materially different from those of conventional banks.

\begin{tabular}{llll}
\multicolumn{5}{c}{$\begin{array}{l}\text { Table 2. Growth Rates of Domestic Credit Provided by Banking Sectors: GCC Countrie } \\
\text { and Benchmarks }\end{array}$} & $\begin{array}{l}\text { Average Growth } \\
\text { Rate of Credit } \\
(2000-2007)\end{array}$ & $\begin{array}{l}\text { Average Growth } \\
\text { Rate of Credit } \\
(2008-2009)\end{array}$ & $\begin{array}{l}\text { \% Point } \\
\text { Change in } \\
\text { Crisis Years }\end{array}$ \\
\hline Country/Aggregate & 15.3 & 18.6 & 3.3 \\
\hline Middle Income Benchmark & 17.6 & 6.0 & -11.6 \\
Iran & & & \\
High Income Benchmark & 7.7 & 2.9 & -4.8 \\
High Income IBC Average & 19.0 & -3.6 & -22.6 \\
Bahrain & 19.5 & 26.1 & 6.6 \\
Kuwait & 17.1 & 8.7 & -8.4 \\
Qatar & 29.6 & 36.1 & 6.5 \\
Saudi Arabia & 1.3 & -120.1 & -121.4 \\
United Arab Emirates & 27.4 & 31.4 & 4 \\
\hline Source: World Development Indicators, World Bank Data Bank
\end{tabular}

\section{Private Saving}

Table 3 presents the results of a panel regressing private savings rates in the six Islamic banking countries on a number of potential explanatory variables, including for each country a variable tracking the development of Islamic banking in that country. I use a fixed effects estimation in order to account for the potential effects of excluded variables and include below results for all potential determinants of private saving in order to compare my findings to those presented by Masson et al. in 1998.

An initial observation is that these results closely corroborate those presented by Masson et al., with coefficients on all terms except per capita GDP relative to the United States showing the same sign and similar magnitude. These are also the results one might expect from standard economic intuition. Among the determinants that are statistically significant in this model, households save in response to 
government dissaving and current spending, a higher current account balance is correlated with higher private saving, and a higher dependency ratio is correlated with lower private savings other things equal.

\begin{tabular}{lll}
\multicolumn{3}{c}{ Table 3. Determinants of Private Saving: Results from six Islamic Banking Countries } \\
an Islamic banking dummy. & Coefficient & $|t|$ \\
\hline Variable & 7.35 & 4.40 \\
\hline Islamic banking development & -1.12 & 12.52 \\
Government budget surplus/GDP & -0.87 & 3.82 \\
Government current expenditure/GDP & 0.03 & 0.23 \\
GDP growth rate & 0.06 & 0.17 \\
Real interest rate & 0.20 & 0.49 \\
Inflation rate & -0.03 & 0.77 \\
Per capita GDP relative to U.S. & 0.57 & 6.79 \\
Current account/GDP & -0.15 & 1.67 \\
Dependency ratio & & \\
Fit statistics & 0.76 & \\
Adjusted $R^{2}$ & 96 & \\
Number of Observations &
\end{tabular}

Note: The dependent variable is the private saving/GDP ratio. Data is for six Islamic Banking Countries over the period 1995-2010.

Source: Authors' calculations.

More interesting, though, is the coefficient on the variable for Islamic banking development in these six countries, which is both positive and significant. While this result does not indicate causation, we can safely conclude that recent Islamic banking development has been correlated with higher private savings rates in the six countries in our analysis. This relationship may be due to a third variable not included in our model that is jointly correlated with both Islamic banking and private saving (e.g. level of Islamic devoutness), but it is strong preliminary evidence that Islamic banking development may have improved financial inclusion in some Muslim-majority countries.

One shortcoming of this model is that, by using country-level rather than bank or household-level data, we can say nothing about the mechanism by which Islamic banks may have caused private savings to increase. An increase in private savings suggests that Islamic commercial banks have complemented conventional banks in the markets in which they now coexist, but it is also difficult to tell to what extent Islamic banks have replaced conventional banks in these markets. As Islamic banking continues to grow and more reliable data sources become available, it would be interesting to reproduce this study using bank-level data. In the meantime, these results shed light on the positive relationship between Islamic banking and financial sector development in Iran, Bahrain, Kuwait, Qatar, Saudi Arabia, and the United Arab Emirates.

\section{Conclusions}

Due to their heavy reliance on nonprofit and lost sharing forms of financing, Islamic commercial banks in today's world are structurally more similar to conventional banks than their proponents claim. This may help to explain why, despite their supposedly conservative borrowing and lending practices, it does not appear that countries with large Islamic banking sectors fared any better than countries relying exclusively on conventional banking in weathering the recent financial crisis.

One tangible distinction of Islamic banks, however, is their classification as complying with Islamic religious norms. Whether this classification is deserved or simply superficial, it has allowed Islamic banks to experience rapid growth among Muslim populations by catering to the needs of devout Muslims who would not otherwise be comfortable depositing money with conventional, riba-based banks. A consequence of this growth, as devout Muslims have gained access to savings vehicles that meet their religious needs, appears to be that private savings rates in countries with significant Islamic banking sectors have increased. 


\section{References}

1. Ali, Salman Syed. Islamic Banking in the MENA Region. ISLAMIC DEVELOPMENT BANK - ISLAMIC RESEARCH AND TRAINING INSTITUTE, 2011. Print.

2. Cihak M., and Hesse H. "Islamic Banks and Financial Stability: An Empirical Analysis." J.Financ.Serv.Res.Journal of Financial Services Research 38.2 (2010): 95-113. Print.

3. Collins, Nick, and Ed Hill. The Role of Islamic Finance in Abu Dhabi's 2030 Vision., 2010. Print.

4. Coughlin, Paul. Standard \& Poor's Islamic Finance Outlook 2010., 2010. Web.

5. Hasan, Maher, et al. "The effects of the global crisis on islamic and conventional banks a comparative study." International Monetary Fund. 2010. /z-wcorg/. http://worldcat.org.

6. Imam, Patrick, Kangni Kpodar, and International Monetary Fund. African Dept. "Islamic banking how has it diffused?" International Monetary Fund. 2010. /z-wcorg/. http://worldcat.org.

7. Iqbal, Munawar, and Philip Molyneux. Thirty Years of Islamic Banking : History, Performance, and Prospects. Basingstoke: Palgrave Macmillan, 2004. Print.

8. Khan, Feisal. "How Islamic is Islamic Banking?" Journal of economic behavior \& organization. 76.3 (2010): 805. Print.

9. Masson, Paul R., Tamim Bayoumi, and Hossein Samiei. "International Evidence on the Determinants of Private Saving."The World Bank Economic Review 12.3 (1998)Print.

10. Musa, Tariq A. "Islamic Banking and the Financial Crisis: Shariah Compliance and Bank Stability in the Arab Gulf." Bachelor's of Arts Harvard College, 2010. Web.

11. Oliver Wyman (Firm). The Next Chapter in Islamic Finance : Higher Rewards but Higher Risks. [New York]: Oliver Wyman, 2009. Print.

12. Ramajo, Julián, Agustín García, and Montserrat Ferré. "Explaining Aggregate Private Saving Behaviour: New Evidence from a Panel of OECD Countries." Applied Financial Economics Letters 2.5 (2006): 311-5. Print.

13. Schmidt-Hebbel, Klaus, Steven Benjamin Webb , and Giancarlo Corsetti. Household Saving in Developing Countries : First Cross-Country Evidence. Washington, DC (1818 H St., N.W., Washington 20433): Country Economics Dept., World Bank, 1991. Print.

14. Solé, Juan, and International Monetary Fund. Monetary and Capital Markets Dept. Introducing Islamic Banks into Conventional Banking Systems. [Washington, D.C.]: International Monetary Fund, Monetary and Capital Markets Dept., 2007. Print.

15. The Consultative Group to Assist the Poor (CGAP), and The World Bank Group. Financial Access 2010: The State of Financial Inclusion through the Crisis., 2010. Print.

16. Warde, Ibrahim. Islamic Finance in the Global Economy. Edinburgh: Edinburgh University Press, 2000. Print.

17. Wilson, Rodney. "The Development of Islamic Finance in the GCC." Kuwait Programme on Development, Governance and Globalisation in the Gulf States (2009) Web.

18. World Bank., and International Monetary Fund. "Financial sector assessment a handbook." World Bank and International Monetary Fund. 2005. /z-wcorg/. http://worldcat.org. 


\section{Endnotes}

1 The Arabic term Shariah translates literally as the "path" or "way" in which Muslims must live their lives.

2 Members include Bahrain, Kuwait, Oman, Qatar, Saudi Arabia, and the United Arab Emirates.

3 A "Z-score" represents the number of standard deviations a bank's returns must drop in order to deplete its equity.

Photo Credits: Wikimedia Commons

Tables, charts, and graphs provided by the author 